DRAGOŠ PETROVIĆ, viši arhivista

Arhiv Jugoslavije

UDK 327(497.1:48)"1918/1945"

Beograd, Vase Pelagića 33

\title{
PREDSTAVNIŠTVA KRALJEVINE JUGOSLAVIJE U SKANDINAVSKIM ZEMLJAMA 1918-1945.
}

\begin{abstract}
APSTRAKT: Tema članka obuhvata formiranje $i$ rad diplomatskih $i$ konzularnih predstavništava Kraljevine Jugoslavije u Skandinaviji, njihovu delatnost izmedu dva svetska rata, približavanje Jugoslavije zemljama severne Evrope i unapređenje privredne saradnje izmedu ovih naroda u toku prve polovine 20. veka.
\end{abstract}

Ključne reči: Kraljevina Jugoslavija, Skandinavija, severna Evropa, diplomatska i konzularna predstavništva, privredna saradnja

Srbija je posle sticanja nezavisnosti na Berlinskom kongresu 1878, kao Kneževina, a od 1882. kao Kraljevina Srbija, formirala svoja diplomatska zastupništva, pre svih u prestonicama velikih sila kao i kod balkanskih suseda. Pred izbijanje Prvog svetskog rata, Srbija je uspostavila i prva konzularna predstavništava u Skandinaviji, koja je tada obuhvatala Dansku, Norvešku i Švedsku, a posle Prvog svetskog rata i Finsku. Zemlje severne Evrope, sa desetak miliona stanovnika, imale su veliku potrebu za poljoprivrednim i stočarskim proizvodima koje je mogla da ponudi Kraljevina Srbija. Izbijanje carinskog rata koji je Austro-Ugarska nametnula Srbiji omogućilo joj je povezivanje sa severnom Evropom početkom 20. veka.

Privredni i ekonomski interesi za širenje srpske trgovine i privrede $\mathrm{u}$ druge delove sveta uticali su da Srbija potraži nova tržišta i sklopi prve trgovinske ugovore sa zemljama severne Evrope. Kraljevina Srbija je sa Kraljevinom Švedskom sklopila prvi trgovinski ugovor $1907,{ }^{1}$ a posle dve godine sa Kraljevinom Danskom i Norveškom. ${ }^{2}$ Ovi trgovinski ugovori omogućili su otvaranje počasnih konzularnih predstavništava Srbije u skandi-

${ }^{1}$ Deklaracija o trgovini između Srbije i Švedske od 29. marta/11. aprila 1907, Srpske novine, br. 214 i 299, 1907.

${ }^{2}$ Deklaracija o trgovini između Srbije i Danske, dogovorena u Beču 17/30. novembra 1909, Srpske novine, br. 77, 1910; Deklaracija o trgovini između Srbije i Norveške, dogovorena u Berlinu, od 24. februara/9. marta 1909, Srpske novine, br. 92, 1909. 
navskim zemljama. Ova predstavništva su vodili isključivo tamošnji državljani, imućniji stranci, bankari ili trgovci, koji su bili zainteresovani za proširenje njihove trgovine.

Početkom 20. veka Srbija je odobrila otvaranje prvih honorarnih, to jest počasnih konzulata ili generalnih konzulata u skandinavskim zemljama. Najpre su otvoreni honorarni konzulati u Švedskoj. Još pre sklapanja trgovinskog ugovora Srbije sa Švedskom, Ernst Gustav Hedin je imenovan za počasnog generalnog konzula koji je već početkom 1908. razrešen dužnosti. ${ }^{3}$ Upražnjeno mesto počasnog konzula popunio je Karl Adam Karlson, direktor banke u Stokholmu, juna 1908, a već krajem 1910. unapređen je za počasnog generalnog konzula $\mathrm{u}$ Stokholmu. ${ }^{4} \mathrm{U}$ vreme nastanka počasnog generalnog konzulata u Stokholmu, formiran je i počasni konzulat u Norčepingu 1907, na čelu sa Arturom Hulkvistom. ${ }^{5}$ Pored ova dva počasna predstavništva u Švedskoj, formiran je juna 1908. i počasni generalni konzulat u Kopenhagenu, na čijem čelu je bio Ludvig Tegner, ${ }^{6}$ a krajem 1909. ili početkom 1910. počeo je rad počasni konzulat u Kristijaniji (Oslu), koji je vodio Peter Vinter. ${ }^{7}$

Ubrzo po otvaranju ovih počasnih konzulata u severnoj Evropi, izbijanje Balkanskih ratova privuklo je širu pažnju skandinavskih zemalja, što

${ }^{3}$ Ernst Gustav Hedin (Ernst Hedin) očigledno je bio i pre 1908. počasni konzul u Stokholmu, a razrešen je 14. marta 1908. dužnosti počasnog konzula. - Srpske novine, 29. mart 1908, br. 72, 337.

${ }^{4}$ Karl Adam Karlson (Carl Adam Carlson, Stokholm, 1867-1939), direktor banke, član više trgovačkih, privrednih i akcionarskih društava, počasni konzul u Stokholmu od 4. juna 1908, unapređen 2. decembra 1910. za počasnog generalnog generalnog konzula, podneo ostavku sredinom 1926. Radio je na razvijanju trgovačkih veza, propagandi turizma u Kraljevini Srbiji i Jugoslaviji, slao materijalnu pomoć, bolničke misije, pomagao srpske državljane i vojnike tokom Prvog svetskog rata. - AJ, 334 (Ministarstvo inostranih poslova) 238-626; AJ, 382 (Poslanstvo Kraljevine Srbije i Kraljevine SHS u Švedskoj - Stokholm) 12-39; Srpske novine, br. 135, 18. jun 1908, 639; Isto, 5. decembar 1910, br. 269, 1499; Predrag Krejić, Poslanstvo Kraljevine Srbije i Kraljevine SHS u Švedskoj - Stokholm 1918-1920, Arhiv, br. 1, Beograd 2003, 81.

${ }^{5}$ Artur Hultkvist (Arthur Hultqvist, Norčeping, 1873-1927), direktor akcionarskog društva, počasni konzul u Norčepingu od 4. novembra 1907. - AJ, 334-238-626; Srpske novine, 1907, br. 260; Predrag Krejić, Poslanstvo Kraljevine Srbije i Kraljevine SHS u ŠvedskojStokholm 1918-1920, Arhiv, br. 1, Beograd 2003, 81.

${ }^{6}$ Ludvig Luj Tegner (Ludwig Berthel Nielsen Tegner, Kopenhagen, 1851-1924), bivši generalni konzul Republike Argentine u Kopenhagenu, postavljen je 12. juna 1908. za počasnog konzula, a 9. maja 1920. za počasnog generalnog konzula u Kopenhagenu. - AJ, 334-219-554; Srpske novine, 24. jun 1908, br. 140, 659; Predrag Krejić, Poslanstvo Kraljevine Srbije i Kraljevine SHS u Švedskoj - Stokholm 1918-1920, Arhiv, br. 1, Beograd 2003, 81.

${ }^{7}$ Peter Vinter (Peter Winther), trgovac u Kristijaniji (Oslu), postavljen 18. novembra 1909. za počasnog konzula. Počasni konzulat u Kristijaniji otpočeo je rad jula 1910. Srpske novine, 21. novembar 1909, br. 259, 1249; Isto, 29. jul 1910, br. 164, 921; Predrag Krejić, Poslanstvo Kraljevine Srbije i Kraljevine SHS u Švedskoj - Stokholm 1918-1920, Arhiv, br. 1, Beograd 2003, 81. 
je dovelo do slanja nekoliko vojnih i sanitetskih misija u Srbiju. ${ }^{8}$ Srbija se gotovo istovremeno zainteresovala za skandinavske zemlje neposredno posle izbijanja Prvog svetskog rata i revolucionarnog vrenja u Rusiji.

Vlada Kraljevine Srbije nastupila je početkom 1916. sa agresivnijom diplomatsko-propagandnom akcijom u neutralnim državama, jačanjem međunarodnog položaja, dovođenjem dobrovoljaca, zaštitom srpskih zarobljenika u zemljama Centralnih sila, obezbeđivanjem namirnica i drugih potrepština. Izbijanje februarske, a potom i oktobarske revolucije 1917, dovelo je do izlaska boljševičke Rusije iz Prvog svetskog rata. To je prouzrokovalo slabljenje položaja sila Antante na zapadnom ratištu, a Kraljevina Srbija je izgubila tradicionalnog prijatelja i zaštitnika, što je pogoršalo pozicije kod saveznika. Ovi događaji su prisilili srpsku vladu da gubitak velikog saveznika kompenzuje pojačanim političkim i diplomatskim angažovanjem na međunarodnoj sceni i otvaranjem novih diplomatskih predstavništava. U danima kada je Srbija bila okupirana, otvaranje predstavništava u neutralnim zemljama bilo je potrebno kako bi srpska vlada ojačala svoj međunarodni položaj, uprkos oskudici u svemu. Kraljevina Srbija je krajem 1916. otvorila diplomatska predstavništva u SAD i Španiji, a potom 19171918. u Portugalu, Holandiji, Švajcarskoj, kao i u Švedskoj ${ }^{9}$ i Danskoj, ${ }^{10}$ gde su srpski predstavnici razvili živu propagandu delatnost.

Srpska vlada je najpre otvorila poslanstvo u Stokholmu, oktobranovembra 1917, gde je početkom 1918. za otpravnika poslova upućen Milan Rakić, ${ }^{11}$ a Bogoljub Jevtić postavljen za sekretara poslanstva. Tek što je stigao u Švedsku, Rakić je dobio obaveštenje od Ministarstva inostranih dela (MID) da je zatražen agreman za novog poslanika u Stokholmu. Tamo je već posle nešto manje od dva meseca, iz poverljivih interesa regenta Ale-

${ }^{8}$ AJ, 382-4-19.

${ }^{9}$ Prvi podatak koji ukazuje na početak rada poslanstva u Stokholmu predstavlja ukaz o postavljenju Bogoljuba Jevtića za sekretara poslanstva, od 19. oktobra 1917. Poslanstvo je otpočelo rad verovatno početkom januara 1918, a prvi šef misije bio je književnik i diplomata Milan Rakić, kao otpravnik poslova. Međutim, po njegovom dolasku, postavljen je 18. februara 1918. Boško Čolak-Antić za poslanika i on je stigao tek maja 1918. u Švedsku. Predrag Krejić, Poslanstvo Kraljevine Srbije i Kraljevine SHS u Švedskoj - Stokholm 19181920, Arhiv, br. 1, Beograd 2003, 80-91.

${ }^{10}$ Srpska vlada je 19. oktobra / 1. novembra 1917. postavila Milutina Jovanovića za šefa misije u Kopenhagenu, kao ministra rezidenta, da obrazuje poslanstvo za Dansku i Norvešku. Kako je on određen i za Norvešku, otputovao je u maju za Oslo. - Arhiv Srbije, Poslanstvo Kraljevine Srbije u Kopenhagenu; Predrag Krejić, Poslanstvo Kraljevine Srbije i Kraljevine SHS za Dansku i Norvešku - Kopenhagen 1918-1920, Arhiv, br. 1, Beograd 2004, 103-117.

${ }^{11}$ Milan Rakić (Beograd, 1876 - Zagreb, 1938), diplomata i književnik. Imenovan je krajem 1917. za otpravnika poslova u Stokholmu. Poslat je juna 1918. u London, a već jula 1918. za poslanika u Kopenhagenu. Posle ukidanja poslanstva u Kopenhagenu 1920. upućen je za poslanika u Sofiji i docnije u Rimu. - AJ, 334-187-510, dosije Milana Rakića. 
ksandra, za poslanika u Stokholmu 21. februara 1918. postavljen Boško Čolak Antić, ${ }^{12}$ gde je stigao tri meseca kasnije. Rakić je u novembru iste godine stupio na dužnost poslanika u Danskoj, dok je poslanstvo u Kopenhagenu radilo još od marta 1918. godine. ${ }^{13}$ Otvaranje ova dva diplomatska predstavništva omogućilo je ne samo uspešnije praćenje situacije u Rusiji, već i efikasnije veze sa srpskim vojnim i diplomatskim osobljem, kao i brojnom srpskom kolonijom koja se tamo našla u nezavidnoj situaciji, a $u$ saradnji sa danskim Crvenim krstom organizovana je pomoć srpskim ratnim zarobljenicima u Nemačkoj i Austro-Ugarskoj.

Već prvim Predlogom budžeta državnih rashoda i prihoda bilo je predviđeno da Kraljevina SHS ima poslanstva u svega 18 država, među kojima se nisu pominjala zastupništava u Danskoj i Švedskoj. ${ }^{14}$ Kraljevina SHS, u cilju smanjenja troškova, odlučila je da ukine ova diplomatska predstavništva i posle nešto više od dve godine postojanja ona su prestala sa radom. ${ }^{15}$ Međutim, posle Oktobarske revolucije i povlačenja diplomatskog osoblja Kraljevine Srbije (odnosno Kraljevstva Srba, Hrvata i Slovenaca) iz Petrograda, pisanjem za štampu i informišući ih o događajima u Sovjetskom Savezu i na severu Evrope, kao i zalaganjem kod Nikole Pašića, ${ }^{16}$ profesor filozofije dr Ivan St. Šajković iz prestonice novoformirane Republike Finske ${ }^{17}$ Helzingforsa (Helsinki), uticao je da se 1. avgusta 1922. otvori gene-

${ }^{12}$ Boško Čolak-Antić (Kragujevac, 1870 - Beograd, 1949) oficir, maršal dvora i diplomata. Imenovan je 21. februara 1918. za poslanika u Stokholmu, premešten decembra 1920. za poslanika u Bukureštu. - AJ, 334-74-219, AJ, 334-203-526, dosije Boška Čolak Antića.

${ }^{13}$ Poslanstvo u Kopenhagenu vodio je od otvaranja Milutin Jovanović (Zaječar, 1880 - Beograd, 1963), sestrić Nikole Pašića, kao sekretar poslanstva, od marta 1918, do dolaska poslanika Milana Rakića, kada je Jovanović ukazom upućen u Bern. - AJ, 334-159482, dosije Milutina Jovanovića.

${ }_{14}$ Predlog budžeta državnih rashoda i prihoda Kraljevine SHS za 1919/1920, Beograd 1919, 206-207.

${ }^{15}$ Poslanstvo Kraljevine SHS u Stokholmu ukinuto je 8. decembra 1920. - AJ, 33494-302.

${ }^{16}$ Pismo Nikoli Pašiću, 26. novembar 1919. - AJ, 334-17-46.

${ }^{17}$ Ivan S. Šajković, (Nakućani, 1875 - Švedska, 1948), filozof, profesor, publicista, diplomata. U Rusiji je bio direktor realke u Kuokalama u Finskoj, profesor Imperatorske istočne akademije, direktor Slovenske trgovinske komore u Petrogradu, a u vreme Prvog svetskog rata bio je u službi srpskog poslanstva u Petrogradu. U Finskoj je postavljen 28. aprila 1923. za dijuristu i praktično je vršio dužnost konzula u Helsingforsu. Ukidanjem konzulata premešten je 25. jula 1926. za zvaničnika dnevničara poslanstva u Varšavi, ali je ostao u Finskoj i imenovan avgusta 1926. za počasnog konzula u Helsingforsu. Unapređen je 30. novembra 1937. za počasnog generalnog konzula, a zbog incidenta sa finskim diplomatom Talasom razrešen je dužnosti 30. septembra 1938. Ponovo je od 12. aprila 1939. na položaju počasnog generalnog konzula u Finskoj. Zbog sovjetsko-finskog rata privremeno je 11. oktobra 1939. premešten u Stokholm, a posle prekida odnosa sa Finskom, ostatak života je proveo u Švedskoj, gde je 1943. prihvatio posao lektora srpskohrvatskog jezika na Univer- 
ralni konzulat u Helsingsforu u Finskoj, na čije čelo je 6. oktobra 1922. postavljen Dragutin Matanović za generalnog konzula. ${ }^{18}$ Kako Matanović nije mogao da se sporazumeva bez znanja finskog jezika predloženo je da se u službu poslanstva primi Šajković koji je dobro poznavao taj jezik, sredinu, zbivanja i bio jugoslovenski državljanin. Međutim, karijerni Generalni konzulat je opstao nepune četiri godine, jer je ukinut 1. aprila, odnosno maja 1926.

Iako su diplomatska predstavništava u Stokholmu i Kopenhagenu ukinuta, nije prestajao rad počasnih zastupništava na severu Evrope. Počasni generalni konzulat u Stokholmu sredinom 1926. nastavio je da vodi Torsten Larka, sekretar konzulata, ${ }^{19}$ a sa manjim prekidima nastavio je da radi i počasni konzulat u Norčepingu. ${ }^{20}$ Još početkom 20 -ih bilo je predviđeno otvaranjem počasnih konzulata u Malmeu i Geteborgu, ${ }^{21}$ ali su oni otvoreni tek početkom 30-ih godina. ${ }^{22}$ Istovremeno počasni konzulat u Kristijaniji (Oslo), formalno je postojao, ali nije radio sve do imenovanja Sem Eja za počasnog konzula sredinom 1927, koji je 1930. unapređen za počasnog generalnog konzula. ${ }^{23}$ Henri Tegner, sin Luja Tegnera počasnog konzula u Kopenhagenu, nastavio je da vodi počasni konzulat krajem 1924, kao vicekonzul, a zatim od maja 1928, kao počasni konzul. ${ }^{24}$ Iako je bilo pokušaja da se smeni zbog nedovoljne aktivnosti, Henri Tegner je zaslužan za

zitetu u Upsali i docnije u Stokholmu. - AJ, 334-203-526, dosije Ivana Šajkovića; AJ, 334233-606 Počasni konzulati u Finskoj. Srpske novine, 1. jul 1903, br. 147, 973.

${ }^{18}$ AJ, 334 MIP-Personalni odsek, 170-493, dosije Dragutina Matanovića; AJ, 334233-606.

${ }^{19}$ Torsten Larka (Thorsten Larka, Stokholm, 1888 - ?), generalni direktor trgovačke kuće Akciobolaget, direktor pomorske agencije u Stokholmu i brodovlasnik. Larka je sredinom 1926. postavljen za vicekonzula, unapređen je 13. juna 1928. za počasnog konzula u Stokholmu, a 15. maja 1930. za počasnog generalnog konzula. Pod pritiskom poslanika Stražnickog podneo je ostavku krajem 1938. godine. - AJ, 334-238-626.

${ }^{20}$ Posle smrti Artura Hultkvista 1927, Sven Holmberg (Sven Johan Algot Holmberg, Norčeping, 1894 - posle 1955), švedski vicekonzul i sekretar konzulata u Liverpulu, bankar, trgovac, direktor firme Algot Holmberg i sin a. d., izabran je jula 1930. za počasnog vicekonzula u Norčepingu, koji je vodio do 1938. godine. AJ, 334-238-626.

${ }^{21}$ Telegram poslanika Boška Čolak-Antića od 16. septembra 1920. Br. 395 sa predlogom da se formiraju novi počasni konzulati u Malmeu i Geteborgu i vicekonzult $\mathrm{u}$ Stokholmu. - AJ, 334-238-626.

${ }^{22}$ Hari Trap (Harry Trapp, Geteborg, 1893 - ?), armater, brodovlasnik, vlasnik firme Borlin, Bersen i Kompani, član upravnih odbora u drugim preduzećima. Postavljen je 3. jula 1930. za počasnog vicekonzula u Geteborgu. - AJ, 334-238-626.

${ }^{23}$ Sam Ej (Sam Eie, Oslo, 1879-1935), inženjer, vlasnik firme za uvoz i izvoz mašina za preradu hartije i za radionicu drvenih saonica, član opštinske uprave, predsednik suda. - AJ, 334-227-587.

${ }^{24}$ Henri Tegner (Henry Edgar Tegner, Kopenhagen 1892 - posle 1952), farmaceut i direktor firme A. S. Bang of Tegner, član akcionarskih društava. - AJ, 334-219-554; AJ, 65263-795. 
održavanje izložbe Jugoslovenske narodne umetnosti u Kopenhagenu marta 1930, za predavanja i prikazivanje filma o Jugoslaviji Jugoslavien, stadt und land. ${ }^{25}$ Početkom 30-ih bilo je predloga i molbi za otvaranje novih počasnih predstavništava u Bergenu, kao pogodnoj luci na moru u Norveškoj, kao i u mestima i lukama u Danskoj - Alborg, Arhus, Vejn i Odense, ali je sve ostalo samo na predlozima. ${ }^{26}$ Posle ukidanja Generalnog konzulata $\mathrm{u}$ Helsingsforu profesor Šajković je uspeo da sredinom 1926. izdejstvuje da u prestonici Finske nastavi rad počasni konzulat, a za uspehe u sklapanju trgovinskog ugovora sa Finskom, ${ }^{27}$ baltičkim zemljama i unapređenju saradnje on je kasnije imenovan za počasnog generalnog konzula.

Početkom 30-ih Kraljevina Jugoslavija je posle reorganizacije Ministarstva inostranih poslova uvidela potrebu otvaranja novih karijernih i počasnih predstavništava za šire privredno povezivanje sa pojedinim državama. Kraljevina je imala zamisao o otvaranju novih diplomatskih zastupništava u Španiji, na Mediteranu, Bliskom istoku i u skandinavskim zemljama, prvenstveno radi povećanja izvoza jugoslovenske robe i sirovina. Posle pokušaja da se otvori poslanstvo u Tokiju 1929, otvoreno je otpravništvo poslova u Rigi juna 1929. koje je zbog velike ekonomske krize početkom 1933. ukinuto. $^{28}$ Posle svetske privredne krize, polovinom 30 -ih godina, jugoslovenska diplomatija je pokazala još veće interesovanje da pronađe nova tržišta za jugoslovensku robu otvaranjem novih karijernih i počasnih predstavništva u Španiji, Švedskoj, Bliskom istoku i Mediteranu.

Posle atentata na Milana Stojadinovića, izvršenog 6. marta 1936, rekonstrukcijom vlade učvršćen je položaja njenog predsednika i omogućeno da kabinet razvije svoj program na političkom i ekonomskom planu. Ekonomski program bio je osnovno težište vladine politike i obuhvatao je jačanje državne intervencije u privredi, razvijanje saobraćaja, javne radove, stvaranje teške, mašinske i hemijske industrije sa snažnim podsticanjem i kontrolom spoljne trgovine. ${ }^{29}$ Iako je Nemačka postala prvi spoljnopolitički partner Kraljevini Jugoslaviji ona je pojačala svoju privrednu aktivnost pre-

${ }^{25}$ Otvaranju izložbe prisustvovale su brojne ličnosti iz političkog, privrednog i kulturnog života Danske sa kraljicom i princezom na čelu. - AJ, 334-303-922; AJ, 65-263-795.

${ }^{26}$ Zavod za unapređenje spoljne trgovine predložio je 14. decembra 1932. Joakima Hanzena (Joachim Hansen), za počasnog konzula u Bergenu. - AJ, 334-227-587; AJ, 334219-554.

${ }^{27}$ Privremeni trgovinski sporazum sa Finskom sklopljen je 29. januara 1929. u Berlinu. - AJ, 65 (Min. trgovine i industrije KJ) 263-795; Službene novine, br. 216, 16. septembar 1929, 1573.

${ }^{28}$ Posle ukidanja otpravništva poslova u Rigi 1933, Kraljevina Jugoslavija je tek aprila 1939. nameravala da otvori diplomatsko predstavništvo u Rigi. - AJ, 334-87-267; AJ, 334-127-443.

${ }^{29}$ Vlade Srbije, Beograd 2005, 349. 
ma zapadnim demokratijama, pa i prema zemljama gde do tada nije imala veću razmenu.

Predsednik vlade Milan Stojadinović, $\mathrm{u}$ isto vreme i ministar inostranih poslova, opredelio se za državnu intervenciju da bi pospešio privredni razvoj zemlje. U tu svrhu je izvršio promene u Ministarstvu inostranih poslova gde je, pored pomoćnika ministra inostranih dela za politička pitanja, 9. maja 1936. imenovao Milivoja Pilju, ${ }^{30}$ kao privrednog eksperta Ministarstva za trgovinu i industriju za privrednog pomoćnika ministra inostranih poslova. ${ }^{31}$

Pilja je dolaskom za pomoćnika ministru Milanu Stojadinoviću dobio dužnost da vodi sve ekonomske poslove MIP-a i da se stara o koordinaciji pojedinih mera privrednih resora sa interesima jugoslovenske spoljne politike. Imao je zadatak da obezbedi ne samo harmoničnu saradnju privrednih resora u MIP-u, već i jedinstveno vođenje spoljne i privredne politike. Obrazovan je i Odbor za koordinaciju u kojem su se uz Pilju nalazili i predstavnici drugih ministarstava (finansija; trgovine i industrije; poljoprivrede; saobraćaja; vojske i mornarice). Pripremao je materijale i vodio trgovinske pregovore sa inostranim predstavnicima, zastupao Kraljevinu Jugoslaviju na međunarodnim privrednim konferencijama i u Društvu naroda, sporazumno i u saradnji sa drugim ministarstvima. Izrađivao je stručne predloge o vođenju privredne politike na osnovu proučavanja međunarodne privredne situacije. Od posebnog značaja za MIP je bilo to da je mogao po ubrzanoj proceduri da podnosi ministru i Ministarskom savetu predloge o otvaranju novih diplomatsko-konzularnih predstavništava $\mathrm{u}$ inostranstvu, ukoliko to privredni interesi diktiraju, što je Milan Stojadinović, predsednik vlade i ministar inostranih poslova, svojim potpisom i potvrđivao. ${ }^{32}$

Njegovim dolaskom za ekonomskog pomoćnika ministra inostranih poslova u diplomatsko-konzularnim predstavništvima više nisu bili bitni samo politički izveštaji, već su se sve više tražili privredni i ekonomski izveštaji sa pojedinih područja. Milivoje Pilja je brzo zaključio u kakvom su stanju bili privredno-ekonomski odnosi Kraljevine Jugoslavije sa pojedinim zemljama. Već 31. avgusta 1936. uputio je predsedniku vlade Milanu Stojadinoviću analizu jugoslovenske trgovinske politike. Izneo je i predloge za popravljanje trgovinskih odnosa sa pojedinim zemljama. Ustanovio je potpuno pomeranje jugoslovenskih tržišta $u$ inostranstvu izazvanog velikom ekonomskom krizom i ukazao na potrebu da se privredna politika Kraljevine mora preorijentisati. Jugoslovenska privredna politika $u$ tom trenutku

${ }^{30}$ Milivoje M. Pilja (Sombor, 1887 - ?) učitelj, privredno-ekonomski ekspert, pomoćnik ministra MIP-a za privredna pitanja. - AJ, 334-183-506 dosije Milivoja Pilje; Stanislav Sretenović, Dučić u Rimu, Beograd 2002, 43.

${ }^{31}$ Obaveštenje od 4. jula 1936. o postavljanju Milivoja Pilje za ekonomskog pomoćnika ministra inostranih poslova 9. maja 1936. - AJ, 334 MIP Protokol 743-2120.

${ }^{32}$ Isto. Materijali o dužnostima ekonomskog pomoćnika ministra inostranih poslova. 
bila je usmerena uglavnom prema razvijenijim privredama svega 4-5 zemalja, posebno prema Italiji, Nemačkoj i Austriji. Ukazao je na rezultat italijansko-etiopskog rata i jugoslovensko sprovođenje međunarodnih sankcija prema Italiji, što je potpuno izmenilo privredne odnose prema Italiji. Tada se, međutim, umesto Italije kao glavnog uvoznika jugoslovenskih proizvoda pojavila Nemačka, koja je već nadmašila njenu privrednu razmenu. Smatrao je opasnim po Jugoslaviju da se njena privreda praktično veže za samo jednu državu i da ta robnonovčana razmena sa njom pređe $40 \%$, što se krajem 30-ih godina i desilo u razmeni sa Nemačkom.

Milivoje Pilja je predložio stvaranje nove jugoslovenske spoljne privredne politike koja je išla u tri pravca. Prvi pravac je bio usmeren prema Velikoj Britaniji, Holandiji, Skandinaviji i baltičkim zemljama, drugi prema jugu, ka Španiji koja je mogla da zameni Italiju, a treći prema severnoj Africi, Egiptu, Bliskom istoku, Palestini, Iraku i Persiji. U sprovođenju ovoga plana Pilja je predvideo otvaranje novih predstavništava, $\mathrm{u}$ prvom redu $\mathrm{u}$ ekonomskim centrima zemalja gde Jugoslavija do tada nije imala nijedno predstavništvo ili ih je imala u nedovoljnom broju. Prvenstveno se to odnosilo na Skandinaviju i baltičke zemlje, basen Sredozemnog mora, Južnu Ameriku, kao i na zemlje Bliskog istoka. Zalagao se za otvaranje poslanstava u Stokholmu, Teheranu i Rio de Žaneiru. Ukazao je na ekonomske odnose koji su poslednjih godina 1934-1935. bili sve bolji, jer je trgovački promet između Jugoslavije i Skandinavije iznosio 50 miliona dinara, turistički promet iz nordijskih zemalja u Jugoslaviju bio je od 1932. u stalnom porastu. ${ }^{33}$ Takođe je predvideo otvaranje nekoliko konzularnih predstavništava u Alžiru, Barseloni, Egiptu, Siriji, Velikoj Britaniji i Holandiji. ${ }^{34}$

Predloge Milivoja Pilje o širenju jugoslovenske privredne politike $u$ tri nova pravca, Stojadinović je uglavnom prihvatio i odlučio da se otvore nova diplomatska predstavništva. ${ }^{35}$ Tako je već 30 . septembra 1936. otvoreno poslanstvo u Stokholmu, a krajem 1936. Generalni konzulat u Jerusali$\mathrm{mu}$ i obnovljen rad Generalnog konzulata u San Francisku. ${ }^{36}$

33 Statistički pregled s kraja 1935. o robnoj razmeni uvoz-izvoz, sa svakom pojedinačnom zemljom Skandinavije, baltičkih republika i Palestinom. - AJ, 334-61-173.

${ }^{34}$ Projekat nove jugoslovenske diplomatske i trgovinske politika koji je predložio Milivoj Pilja 31. avgusta 1936, dostavljen je Milanu Stojadinoviću, predsedniku vlade i ministru inostranih poslova. Pilja je u predlogu izneo da će u novim konzulatima broj činovnika biti sveden na minimum sa šefom i sekretarom. - AJ, 334-61-173.

${ }^{35}$ Milan Stojadinović je osim predloga Milivoja Pilje imao i izveštaj Svetozara Rašića, generalnog konzula u Milanu, od 28. januara 1936. sa obrazloženjem o potrebi otvaranja jednog diplomatskog predstavništva za Švedsku, Norvešku, Dansku i Finsku, sa pregledom jugoslovenskih počasnih predstavnika u tim zemljama i uz detaljni opis proizvoda koje mogu da izvezu ove zemlje i proizvodi koje mogu da uvezu iz Jugoslavije. - AJ, 334-61-173.

${ }^{36}$ AJ, 334-131-450. 
Posle više od 15 godina formalno je 30. septembra 1936. obnovljeno Poslanstvo Kraljevine Jugoslavije u Stokholmu, ali je otpočelo rad tek krajem 1936. godine. Međutim, tek po dolasku u Stokholm, ${ }^{37}$ prijema kod Sandlera, ministra inostranih poslova Švedske 13. februara i predaje akreditivnih pisama princu prestolonasledniku 22. februara 1937, Milorad Stražnicki je kao poslanik praktično počeo da radi. ${ }^{38}$ Kasnije je akreditovan u Danskoj, Norveškoj i Finskoj, odlaskom u njihove prestonice. ${ }^{39}$

Poslanstvo u Stokholmu je trebalo da osim poslanika ima tri sekretara, jer je predviđen delokrug rad za Dansku i Norvešku, gde bi poslali po jednog sekretara, na dužnost trgovačkog atašea. U poslanstvu su pored poslanika, radili još Milutin Milovanović, savetnik, Todor Ristić, sekretar, Dragoljub Bogić, pisar, protokolista, dva dnevničara, dve sekretarice daktilografkinje, služitelj dnevničar, dva služitelja i dva šofera, ukupno 14 ljudi.

Otvaranjem poslanstva u Stokholmu usledili su čvršći diplomatskoprivredni kontakti kraljevina Jugoslavije i Švedske. Pojačana je privredna saradnja sa Švedskom, ali i sa svim drugim skandinavskim zemljama. Švedska je još 1931. podnela projekat ugovora o trgovini i plovidbi, koji je Jugoslavija tek po obnavljanju diplomatskog zastupništva u Stokholmu prihvatila kao bazu za novi tekst jugoslovensko-švedskog ugovora, a u toku aprila i maja 1937. održani su pregovori o sklapanju novog trgovinskog ugovora. Jugoslovenska privredna delegacija sklopila je brzo nove trgovačke ugovore sa Danskom, ${ }^{40}$ Norveškom i Švedskom, ${ }^{41}$ a sa Finskom su pregovori nasta-

${ }^{37}$ Izveštaj Stražnickog od 25. februara 1937. Stojadinoviću, predsedniku i ministru inostranih poslova o dolasku u Stokholm. - AJ, 382 (Poslanstvo Kraljevine Jugoslavije u Švedskoj - Stokholm) 4-15.

${ }^{38}$ Dr Milorad Stražnicki (Križevci, 19. novembar 1879), pravnik, profesor, diplomata. Bio je poslanik u Buenos Ajresu od 1929. do 1931, Hagu 1931-1934, a od 1936. do 1941. u Stokholmu. Prešao je u diplomatsku službu NDH decembra 1941. i neko vreme je bio poslanik u Budimpešti. Osuđen je 1945. na dve godine prisilnog rada, ali je zbog starosti i zdravstvenog stanja ostatak života proveo u kućnom pritvoru. - AJ, 334-195-518, dosije Milorada Stražnickog; Hrvatski narod, 5. decembar 1941, 4. januar 1942, 24. januar 1942; Ustaški diplomata Stražnicki osuđen na dve godine prisilnog rada. Politika, 20. avgust 1945, br. 12065, str. 2; Stanoje Stanojević, Narodna enciklopedija srpsko-hrvatska-slovenačka, knj. 4, 518 .

39 Stražnicki je akreditovan je 29. marta 1937. u Danskoj, jula-avgusta 1937. u Norveškoj, a septembra 1938. u Finskoj. AJ, 382-4-16; AJ, 382-4-17; AJ, 382-4-18.

${ }_{40}$ Uredba o trgovinskom sporazumu između Kraljevine Jugoslavije i Kraljevine Danske od 13. maja 1937, potpisana u Kopenhagenu 1. maja 1937, stupila je na snagu 15. maja 1937. - Službene novine, br. 110, 18. maj 1937, 519; Zakon o ugovoru o koncilijaciji, arbitraži i o sudskom raspravljanju između Kraljevine Jugoslavije i Kraljevine Danske od 29. septembra 1937, potpisan u Beogradu 14. decembra 1935, AJ, 382-4-14; Službene novine, br. 239, 21. oktobar 1937, 1637.

${ }^{41}$ Zakon o ugovoru o trgovini i plovidbi između Jugoslavije i Švedske od 23. avgusta 1938, sa završnim protokolom i o protokolu o reglementaciji trgovačkih razmena, od 14. 
vljeni 1938. godine. ${ }^{42}$ Delegacija koju su sačinjavali Milivoje Pilja, pomoćnik ministra inostranih poslova, Ivo Belin, viceguverner Narodne banke i Ante Pavelić, sekretar delegacije i službenik MIP-a, sklopila je aranžmane sa skandinavskim zemljama, koji bi omogućili povećanje jugoslovenskog izvoza radi otklanjanja minusa od 42,6 miliona dinara prema Švedskoj i 26,6 miliona dinara prema Norveškoj, radi obezbeđenja uvoznih dozvola za jugoslovenske izvozne artikle i drugo. ${ }^{43}$

Formiranje diplomatskog predstavništva Kraljevine Jugoslavije $u$ Stokholmu uticalo je da se delatnost počasnih konzulata usmeri uglavnom ka privrednom, kulturnom i propagandno-turističkom polju. Krajem 1937. vođeni su razgovori sa firmom Svenska Orijent Line o uspostavljanju direktne pomorske linije Švedska-Jugoslavija u vezi sa izvozom i uvozom robe, kao i u smislu uspostavljanja turističke linije. Tada je ponovo oformljen turistički biro u Stokholmu. ${ }^{44}$

Teodor Olesen, počasni generalni konzul u Kopenhagenu, organizovao je novembra 1938. otvaranje izložbe jugoslovenske grafičke umetnosti u Odenseu, pod nazivom Upoznajte Jugoslaviju. Izložba je kasnije otvorena $\mathrm{u}$ drugim mestima Skandinavije. Posle posete Jugoslaviji, Anders Nilsen, počasni vicekonzul u Malmeu, priredio je 16. decembra 1938. izložbu jugoslovenskih narodnih rukotvorina i ćilima, kada je prikazan i turističko-propagandni film o Jugoslaviji. Zaslugom Hari Trapa, počasnog vicekonzula u Geteborgu, preneta je i februara 1939. otvorena izložba jugoslovenske grafičke umetnosti i izložba jugoslovenskih narodnih rukotvorina u Geteborgu. Međudržavna udruženja obično su nastajala u prestonicama, ali su takva društva podržavana i u manjim sredinama, kao što je bilo švedsko jugoslovensko društvo u Geteborgu, nastalo februara 1939. Počasni konzulat u Oslu tražio je novembra 1939. od jugoslovenskog predstavništva filmske žurnale o Jugoslaviji za propagandu. Inicijativom jugoslovensko-norveškog društva održana je 15. februara 1940. izložba fotografija Zagrebačkog foto-kluba u Oslu. Postojali su i drugi načini da se predstavi Jugoslavija u Skandinaviji, kao predavanja i muzički programi. Josip Smodlaka, diplomata i jugoslovenski političar, održao je nekoliko predavanja u Kopenhagenu tokom novembra 1937, a Artur Almhult, glavni urednik švedskog enciklopedijskog rečnika i sekretar švedsko-jugoslovenskog udruženja, oktobra 1939. u Stokholmu. Književnica i novinarka Margit Muskat, koja je propu-

maja 1937, stupio na snagu 29. juna 1937. - AJ, 382-4-14; Službene novine, br. 254, 5. novembar 1938, 1231.

${ }^{42}$ AJ, 382-4-18.

${ }^{43}$ Izveštaj Pilje iz Beograda - poslaniku Stražnickom u Stokholm, 7. jun 1937. AJ, 382-4-14

${ }^{44} \mathrm{AJ}, 382-4-15$. 
tovala i pisala o Jugoslaviji, održala je švedskoj omladini predavanje preko radija februara 1940, a Ejnar Digve, profesor Univerziteta u Kopenhagenu i predsednik dansko-jugoslovenskog društva 6. marta 1941, uz film o arheološkom bogatstvu Jugoslavije. Umetnički programi iz Jugoslavije pomno su praćeni u skandinavskim zemljama uz pozitivne kritike, kao Gotovčeva opera Ero s onoga svjeta, odigrana početkom 1941. u Helsinkiju. ${ }^{45}$

Kada se poslanik Stražnicki priklonio Nezavisnoj Državi Hrvatskoj, jugoslovenska izbeglička vlada u Londonu postavila je za poslanika Aleksandra Avakumovića, ${ }^{46}$ koji je tu ostao do penzionisanja oktobra 1944. Pred Drugi svetski rat i u toku rata broj ljudi u poslanstvu se stalno povećavao. Uslovi za rad su bili veoma otežani i uz poslanika su radili Nikola Nadić, savetnik, Dragoljub Vukčević, šef kancelarije i ataše za štampu, Krsto Jandrijević, nerazvrstani služitelj, Henrik Benda i Arvid Johanson, služitelji dnevničari. Profesor dr Ivan Šajković sa porodicom stigao je 29. juna 1941. u poslanstvo i nastavio da vrši svoju dužnost počasnog generalnog konzula u Helsinkiju, jer su mu u Finskoj zabranili rad. Prve dve ratne godine, pa i duže, u Poslanstvu su radili još profesor Bogoljub Krajčik, sekretar ministra prosvete, kao ataše, Karin Aralica, supruga slikara Stojana Aralice, kao sekretar kancelarije, dr Berislav Bošković, pravnik i šef kabineta ministra za snabdevanje i ishranu, kao činovnika poslanstva. Vladislavu Markoviću, savetniku MIP-a koji je uspeo sa suprugom da stigne u Stokholm, Švedska nije dopustila da ostane duže, smatrajući da jugoslovensko poslanstvo ne može stalno da se povećava. Poslanstvo je nastavilo da funkcioniše tokom rata i posle svih političkih, privrednih i društvenih promena. Odlukom predsednika vlade Šubašića i jedinstvene vlade DFJ, krajem 1944. i početkom 1945, u novim okolnostima nastavilo je da radi jugoslovensko poslanstvo u Stokholmu na čelu sa novim poslanikom, Rajkom Đermanovićem. ${ }^{47}$

Kraljevina Jugoslavija je pred Drugi svetski rat imala samo jedno diplomatsko predstavništvo u Stokholmu, koje je radilo u Skandinaviji, od ukupno 48 karijernih zastupništava, dok je od sedamdesetak počasnih predstavništava u severnoj Evropi delovalo svega 7 počasnih zastupništava i

${ }^{45}$ AJ, 334-303-922; AJ, 382-4-15; AJ, 382-4-16; AJ, 382-4-17; AJ, 382-4-18.

${ }^{46}$ Aleksandar G. Avakumović (Zemun, 1896 - oko 1970) pravnik, docent, diplomata, ambasador. - AJ, 334-133-456 dosije Aleksandra Avakumovića. Bogdan Krizman, Jugoslovenske vlade u izbeglištvu, 1941-1943, knj. 1, Zagreb, Beograd 1981; Branko Petranović, Jugoslovenske vlade u izbeglištvu, 1943-1945, knj. 2, Zagreb, Beograd 1981; Srpski biografski rečnik, knj. 1, Novi Sad 2004, 40.

${ }^{47}$ Rajko Đermanović (Zagreb, 1898 - Stokholm, 1991) političar, pravnik, profesor, diplomata. Postavljen ukazom kraljevskih namesnika 11. maja 1945. za poslanika DFJ u Švedskoj i potom akreditovan i u Norveškoj. Opozvan je krajem 1947. iz Stokholma. - Službeni list, 15. maj 1945, br. 32, str. 263, Politika, 13. maj 1945, br. 11978, str. 2; Službeni list, 31. decembar 1947, br. 111, str. 1585. 
to 4 počasna generalna konzulata $\mathrm{u}$ Kopenhagenu, Oslu, Stokholmu i Helsinkiju, počasni konzulat u Geteborgu, kao i 2 vicekonzulata u Norčepingu i Malmeu. ${ }^{48}$

Dragoš Petrović

\author{
THE YUGOSLAV DIPLOMATIC REPRESENTATIONS \\ IN SCANDINAVIAN COUNTIRES 1918-1945
}

\title{
Summary
}

The creation of the first diplomatic representatives of the Kingodom of Serbia (later SHS, Yugoslavia) leaded to the estabilishing of the contacts with the Northern Europe, creation of the economic agreements and initial cooperation. Two diplomatic representatives were formed in Stockholm and Kopengagen, but after the World War I they were closed in 1920. Since thier colosure, the honorary consulates remained acitive. After the reorganisation of the Yugoslav Ministry of Foreign Affairs in the beginning of the 1930-ties, diplomatic representatives (embassy) was re-estabilished, with the intention to develop the ecomical relations and the trade with Northern Europe countries. The economical treaties were renewed in 1937 to improve the export of the Yugoslav goods in that part of Europe. The Yugoslav embassy in Stockholm have the responsiblity over the consulates and represenatives in Sweeden, Danemark, Norway and Finland. During the World War Two it became one of the most importnat diplomatic centres of the Yugoslav Government in exile.

${ }^{48}$ Spisak počasnih konzulata KJ od 13. maja i 9. decembra 1937 - AJ, 334-61-174. 